\title{
DESIGN E EMBALAGENS BIOATIVAS: REVESTIMENTO COMESTÍVEL PARA MORANGO (FRAGARIA ANANASSA) A PARTIR DE QUITOSANA RETICULADA.
}

Clara de Melo Trindade

Escola de Design - Universidade do Estado de Minas Gerais (UEMG)

claramtrindade@gmail.com

Eliane Ayres

Escola de Design - Universidade do Estado de Minas Gerais (UEMG)

eayres.pu@hotmail.com

Resumo: Atendendo a demanda dos consumidores em obter alimentos com maior qualidade e uma necessidade ambiental na redução dos resíduos de embalagens descartáveis, o design de embalagens tem ganhado maior atenção nos últimos anos por prolongar a vida de prateleira dos alimentos, manter a qualidade no interior do produto e possuir características biodegradáveis e antimicrobianas. Este projeto visa obter e analisar filmes bioativos comestíveis para recobrimento de morangos baseados em quitosana e ácidos carboxílicos. Os filmes serão caracterizados quanto ao aspecto visual, a sua hidrofilicidade, e ao grau de inchamento em água, além de comparar a alteração de cor de morangos sem recobrimento (controle) e revestidos com filmes de quitosana utilizando colorímetro de coordenadas RGB. O estudo visa demonstrar que o processo de senescência dos morangos revestidos é mais lento do que aquele na fruta controle. Com essa pesquisa é possível demonstrar que o design aliado à ciência de materiais é uma ferramenta importante que pode contribuir para melhorar a relação com os consumidores e a vida útil dos alimentos.

Palavras-chave: morango, quitosana, armazenamento, filmes comestíveis, embalagem ativa. 